\title{
Medication Infrastructure Development in Germany
}

\author{
Stefan Klein and Stefan Schellhammer
}

\subsection{Introduction}

In principle, the advantages of the digital transformation of the German healthcare system have been recognized by stakeholders and policy-makers. The need to move forward has been emphasized by governmental and representative bodies. Funding has been allocated to finance pilot projects and infrastructure development.

The electronic health card has been and continues to be the flagship of German ehealth initiatives. Its vision is nothing less than to replace most of the manual, paper-based communication processes by secure, digital pathways. Thereby, the initiative aims for providing a nationwide infrastructure on which in the future numerous applications can be build. It is essentially conceived as the entry ticket into the German healthcare system for every health insurance beneficiary.

Yet, so far, the development of the ehealth card in Germany is characterized by delays and significant reductions in the functional scope compared to the original plans. For instance, electronic prescriptions are not any more considered as a priority application. While the government pushes the project further, it remains uncertain when and in what form the first applications will materialize.

Some argue that the "project's sheer size, scale and complexity" is a major cause for its current state (Drews and Schirmer 2015 p. 12). An iterative approach combined with a more balanced economic distribution of costs and benefits is suggested as a more promising way (ibid.). While we do not deny that such arguments are worth to consider, we would like to suggest the notion of "installed base of opposition" in order to make sense of the difficulties plaguing German ehealth initiatives. We have developed and used this concept to trace the development of a rather focused, albeit scalable ehealth project over the last 10 years. The clear focus of the initiative on medication management for

S. Klein $(\varangle) \cdot$ S. Schellhammer

University of Münster, Leonardo-Campus 11, 48149 Münster, Germany

e-mail: stefan.klein@uni-muenster.de; stschell@wi.uni-muenster.de 
polypharmacy patients not only implies significantly fewer stakeholders (patients, doctors, nursing homes, pharmacies) but also allows for a tangible definition of economic benefits as well as improvements to quality of care. The initiative aims to improve medication compliance for polypharmacy patients by providing patient specific medication packs functioning as dose administration aids, called automated drug (or dose) dispensing (ADD). The involved work process is not entirely new but close to the existing practice of blistering pharmacies or blister centres. Especially nursing or care homes and polypharmacy home care patients have been targeted as customers. The initiative aims to automate and informate this process to achieve economies of scale and to reduce errors due to manual blistering.

Ideally, the weekly production of individualized medication packs would be built on key components of a general information infrastructure such as e-prescriptions, consolidated medication plans, and electronic communication between doctors, pharmacists, ADD operators and health insurance providers in order to be able to operate most efficiently. Thus, ADD would benefit from and nicely tie into an existing information infrastructure like the one envisioned by the electronic health card, but it may very well function without such a basis.

In this chapter we will show that this well-focused initiative suffered the same fate as the wider electronic prescription in Germany: It does not feature anymore in the discourse of ehealth applications. In our analysis, we were struck by the lack of an open and substantive discourse among the involved stakeholders. Given the cooperatist and consensus oriented governance of the German health care system, a resistance that ranges from a lack of open discourse to outright blockade is disturbing. Therefore, we come to the conclusion that the slow and cumbersome progress of infrastructure development in the German healthcare sector can be explained by the existence of an installed base of opposition. This interpretation does not bode well for the latest attempt by the government to jumpstart the digital transformation of the German health care sector.

\section{Methods}

In order to capture the public discourse about medication infrastructure development, research for this paper started with the collection and analysis of newspapers, reports, press releases, position papers, blogs, presentations and studies of the health-care community. These documents have been complemented by legal documents and international academic literature, dealing with medication compliance, ADD etc. Moreover, we have interviewed researchers involved in the study of ADD in Germany and Finland, representatives of Kohl Medical, as well as members of the blister community, pharmacists and doctors. An earlier version of this paper was shared with a representative of Kohl Medical for validation purposes. One of the authors gave an invited talk about the European landscape of ADD at a Blister conference in order to solicit further feedback. 


\subsection{One Step Forward Two Steps Back: The Situation of eHealth in Germany}

In 2003, plans to modernize the German healthcare system by eHealth technology were put in place as part of a law by the federal government. In particular it was envisioned that: "From 1 January 2006 all 72 million customers of the health insurance companies in Germany [...] which give access to state health care, should be using a "health card" with a microchip. [This] should make 700 million handwritten prescriptions redundant" (Tuffs 2004, p. 131).

Now, more than 10 years after the envisioned starting date, the system is still far from being operational. In fact, in December 2015 the German parliament passed the so-called "ehealth law" incorporating a roll-out plan to ensure the operation of the electronic health card system by 2018. Although the system has been reduced in its functional scope and now features a step-wise approach including financial incentives to spur adoption, it is still unclear whether the new starting date will be met.

In the following we will briefly revisit the history of the "most extensive e-health communication project in the world" (Tuffs 2004, p. 131).

The initial plans, which passed into law in 2003, listed various functional properties for the electronic health card: Apart from providing data to identify the insured person, it should include data required for the European Health Insurance Card (EHIC) and allow for electronic prescriptions. Furthermore, the card was supposed to support a number of additional applications, such as the use of medical data for emergency treatments, a digital form of communication between physicians and patients (doctor's or referral letters), data necessary for medication safety, an electronic patient record, and information about the donation of organs (§ 291a SGB V).

The initial starting date (of 2006) had to be abandoned in 2005. Instead, a number of field tests were conducted in seven test regions in 2007 and 2008 (Elmer 2014). The introduced solution caused substantial problems partially leading to an extension of the test phase and partly even to the termination of the tests. As a reaction to the failed pilots, the German Medical Association repeatedly positioned itself against the current concept of the eHealth card (Bundesärztekammer 2008). ${ }^{1}$ Furthermore, in 2009, the private insurances retracted from the project.

In response to these developments the government decided to put the project on hold for review after the election in 2009 (Neumann 2009). This led to a reorganization and re-start of the project in 2010. In particular, the stakeholders agreed to reduce the initial scope of the card to just three initial applications: (1) basic patient and insurance data (2) introduction of an emergency data set, and (3) secure communication between health care professionals (VFA 2014). Since then, the introduction of electronic prescriptions has largely disappeared from the political agenda. In 2010 a representative survey among physicians showed that e-prescription is perceived as the application of the health card, which is viewed most skeptically (Institut für Demoskopie Allensbach 2010, p. 19)

\footnotetext{
${ }^{1}$ The German Medical Assembly documented their critical stance also in the memoranda of subsequent years.
} 
Since 1 January 2015 the electronic health card is the exclusive credential to receive medical treatments. About $97 \%$ of all insured patients have received the card (GKV Spitzenverband 2015). Yet, so far even the basic functionality is not online. Because of the newly introduced picture of the patient alongside the stored basic patient data it is mostly seen as an expensive way to curb insurance fraud. Also this basic functionality is facing resistance as doctors do not regard crosschecking the identity and insurance of a patient as their genuine task but as an administrative burden that is passed on by health insurance companies (Bundesärztekammer 2015). Even the first field test of the online patient data seems to be delayed again, jeopardizing the subsequent phases (Borchers 2015).

In December 2015 a new law called "law for secure digital communication and applications in healthcare" has passed the German parliament. It essentially sets clear guidelines and deadlines to ensure the implementation of the ehealth card without further delay (Stafford 2015). For instance, until 1 October 2016 a paperbased medication plan has to be made available for patients, who need at least three medications. In 2018 this is supposed to work electronically. As of 2018, emergency health information can be stored on the ehealth card, if the patient wishes. The online verification and updating of patient data is conceived as one of the first applications to be available nationwide. After the implementation, foreseen until mid2018, the law specifies 1 July 2018 as a deadline after which doctors who do not participate will incur a $1 \%$ reduction of their reimbursement (Bundesregierung der Bundesrepublik Deutschland 2015).

The specific deadlines, milestones, and sanctioning mechanisms as well as financial incentives mentioned in the law suggest a clear roadmap capable to overcome the stalled implementation process. Yet, the reactions to the initial draft of the law raise doubts as to whether the optimism of the federal government in regard to the impact of the law is justified (Bundesärztekammer 2015; Schersch 2015).

\subsection{Case Background}

\subsubsection{Medication Management for Polypharmacy Patients}

Comprehensive medication management for polypharmacy patients (Lochner et al. 2011) has been recognized as a key area of health care in need of improvement and innovations: it affects a growing number of patients, has huge financial implications and ties into broader issues such as patient health and medication safety, medication records, coordination across different medical specialists, and cooperation between medical doctors and pharmacists.

Medication safety and compliance are major issues in the management of medication for polypharmacy patients. Polypharmacy patients are patients who regularly have to take four or more distinct types of medication. They are typically suffering from diseases such as coronary heart disease, congestive heart failure, hypertension, or diabetes mellitus. Given the sheer number of medication and over-the-counter drugs (OTC) taken, there is a high risk of critical interactions. Adverse drug reactions 
and critical interactions among medicines can often be identified and resolved before the actual administration of the drug takes place. However, accurate identification of risks relies on comprehensive information about the current and past medication regime of the patient. Medication safety addresses specifically adverse drug reactions and critical interactions among medicines. Compliance or adherence ${ }^{2}$ focuses on the patients' behaviour in particular in long-term medication therapies.

The response to this set of problems varies across different health care systems. Yet, there is a broad consensus about the key components of a solution (Haefeli et al. 2012):

1. A comprehensive patient medication record to document a patient's medication.

2. A control for critical interactions based on the medication record.

3. Monitoring of the medication effects over time.

4. Dose administration aids to support patients and their helpers to follow the medication regime (dosage and timing).

While we will be looking specifically into dose administration aids throughout this chapter, they are only one component of a comprehensive medication management (Royal Pharmaceutical Society 2013) that typically requires components $(1-3)$ as a prerequisite.

\subsubsection{Automatic Dose Dispensing (ADD) as a Key Component for Medication Management}

Adherence is in particular a problem for chronically ill elderly patients, who constitute the largest segment of polypharmacy patients. The use of dose administration aids, such as the $7 \times 4$ pill box or the weekly blister wallet, is regarded as good practice to support compliance (Corlett 1996): the medication plan is translated into separate physical compartments marked with the assigned day, time and filled with the respective medication. So the physical presence of the medication functions like a reminder to take the assigned medication, a materialized logic of compliance. However, from the patients' or caretakers' point of view, filling pill boxes, is a tedious and therefore error-prone process (Lauterbach et al. 2007). Hence, provisioning of dose administration aids is mandated for specific patients in a number of countries including Australia, Austria, Denmark, Switzerland and The Netherlands based on the assumption of enhanced safety, improved medication adherence, reduced cost and time efficiency (Bell et al. 2013).

Automatic dose dispensing (ADD), the industrial production of patient-specific dose administration aids for solid oral medicines, has been introduced in primary

\footnotetext{
${ }^{2}$ Adherence is the broader concept, which encompasses acceptance (redeeming the prescription), persistence (continuing the medication therapy) and compliance (following the prescriber's instructions) (Düsing 2006, 11). Throughout this chapter we will use adherence and compliance synonymously.
} 
care for home-dwelling elderly patients in a range of countries, such as Denmark, Finland, The Netherlands, Norway and Sweden (Cheung et al. 2014). ADD builds on and extends established practices of arranging medicines in pill boxes, e.g. the widely used $7 \times 4$ pill box has twenty eight separate compartments for pills. Each compartment may contain several pills, which are to be taken at the same time during a day (morning, noon, afternoon, evening). Those aids, blisters packs, blister wallets or collections of sachets, also provide information about patient, medication and schedule for administering the medication. From a patient's perspective, ADD replaces the $7 \times 4$ pill box by sachets or blister packs, each of which contain the pills of the pill box compartments. These blisters are produced and sealed on an industrial level according to industrial quality standards (GMP - good manufacturing practice). Thus, ADD substitutes the manual administration of medication, dose administration aids filled by patients, their careers or pharmacists, or blisters produced manually or (semi-)automatically by pharmacists or regional blister centres. ADD is typically provided across regions or nationwide, it is a way of scaling up the production and provisioning of blisters for quality and efficiency reasons.

\subsubsection{Attempted Infrastructure Innovation}

Given the prevalence of national regulation in health care, we have been studying the public discourse about improving medication management in Germany over the course of 10 years. There has been a broad consensus about the need to improve the safety of medication therapy. Since 2007 a series of action plans to improve the safety of medication therapy have been established and executed (AkDÄ 2007), see also (World Alliance for Patient Safety 2008) and specifically to address the risks and costs of non-compliance (ABDA and KBV 2011a; Arzneimittelinitiative Sachsen-Thüringen 2014; Ärztliches Zentrum für Qualität in der Medizin (ÄZQ) 2011; Bierwirth and Paust 2004; Braun and Marstedt 2011).

Pharmacists and operators of blister centres have been lobbying for the official recognition of the advantages of blistering, i.e. the provision of patient specific dose administration aids in form of blister packs, for years. However, their success and impact has been quite limited. Within the Federation of German Associations of Pharmacists (ABDA) they appear to be regarded as a small special interest group of pharmacists focusing on servicing care homes.

We will be investigating specifically the introduction of industrial automatic dose dispensing (ADD) as an infrastructure innovation in the German healthcare system.

\subsection{Case Presentation}

\subsubsection{From Semi-automated Packaging to Industrial Scale ADD}

In 2000 the first care homes in Germany started to introduce patient-specific blisters packs to their patients ("Patienten-individuelle Verblisterung in Deutschland eine Bestandsaufnahme," 2010). Over the next 16 years a number of pharmacies 
(28 according to the BlisterBlog (http://verblistern.info/blog/) de facto perhaps two or three times as many) and regional blister centers (29 according to the BlisterBlog (http://verblistern.info/blog/)) has commenced their operation to package pills manually or semi-automatically into blister cards or tubular bags. Two associations (BPAV, BVKA) have been founded to represent the interests of these organizations.

\subsubsection{The Design of the ADD Pilot Infrastructure}

In 2005, the regulatory preconditions for the industrial production of patientspecific blisters have been established in principal, however, eligibility criteria, rules for reimbursement and the collaboration between doctors and pharmacists in reviewing medication plans had not been included. Subsequently, two industrial ADD operators $-7 \times 4$ Pharma and AvidiaMed ${ }^{3}$ - have set-up production sites and run trials. The blistering facilities of $7 \times 4$ Pharma had been designed to produce weekly blister packs for polypharmacy patients at a national scale, i.e. up to 100.000 patient specific blisters per day. In parallel a number of blister centers have been set-up by pharmacies at a regional level, which produce blisters for a small number of participating pharmacies. Moreover, a number of pharmacies offer the (manual) production of dose administration aids as an additional, usually complimentary service.

While there are numerous options of how to design ADD, $7 \times 4$ Pharma had opted for key design features for their pilot: They used blisters instead of sachets, in order to increase the quality of the medication packs. $7 \times 4$ Pharma covers a dispensing range or assortment of 400 standard, generic and proprietary substances (Kohl 2010 , p. 10). $7 \times 4$ Pharma operated as a service provider for pharmacies, in collaboration with general practitioners and specialist doctors instead of direct deliveries to care homes and home care patients. They designed a process flow (Fig. 10.1), which illustrates the direct collaboration with doctors, pharmacists and wholesalers and the indirect involvement of patients and insurance providers. Three components of medication management, specifically medication information management are crucial for the operation of ADD:

- Electronic information exchange akin with electronic prescription between ADD operator, physician and pharmacy. ADD assumes up to date comprehensive information about all of patient's prescriptions in order to be able to provide a comprehensive blister of all oral medicines.

- Based on the prescriptions, a consolidated and comprehensive patient medication plan is created.

- A medication list, typically based on active ingredients identifies standard medication and possible substitutes. The medication list can help to deal with the complexity and multiplicity of medicines.

\footnotetext{
${ }^{3}$ As $7 \times 4$ Pharma was the first, most prominent and indeed most controversial attempt to establish ADD in Germany, we have focussed on their case.
} 
The physician issues the prescription

- based on $7 \times 4$ Pharma's range

- 400 different pharmaceuticals in soild oral form

- physician indicates dose

- the correctness of the dosage is verified by a special tool

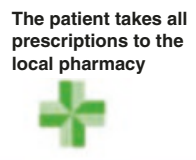

prescriptions to the

The pharmacy registers the prescriptions

- checks for interactions and double

prescriptions

- separate solid oral and other forms

- manages remaining quantities using the $7 \times 4$

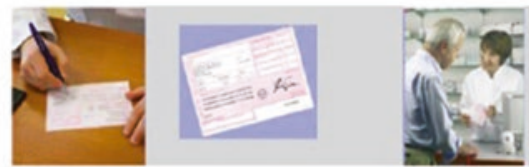

Pharma software

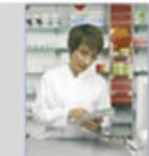

The pharmacy transmits the prescription data to $7 \times 4$ Pharma

- specifications for solid oral forms only

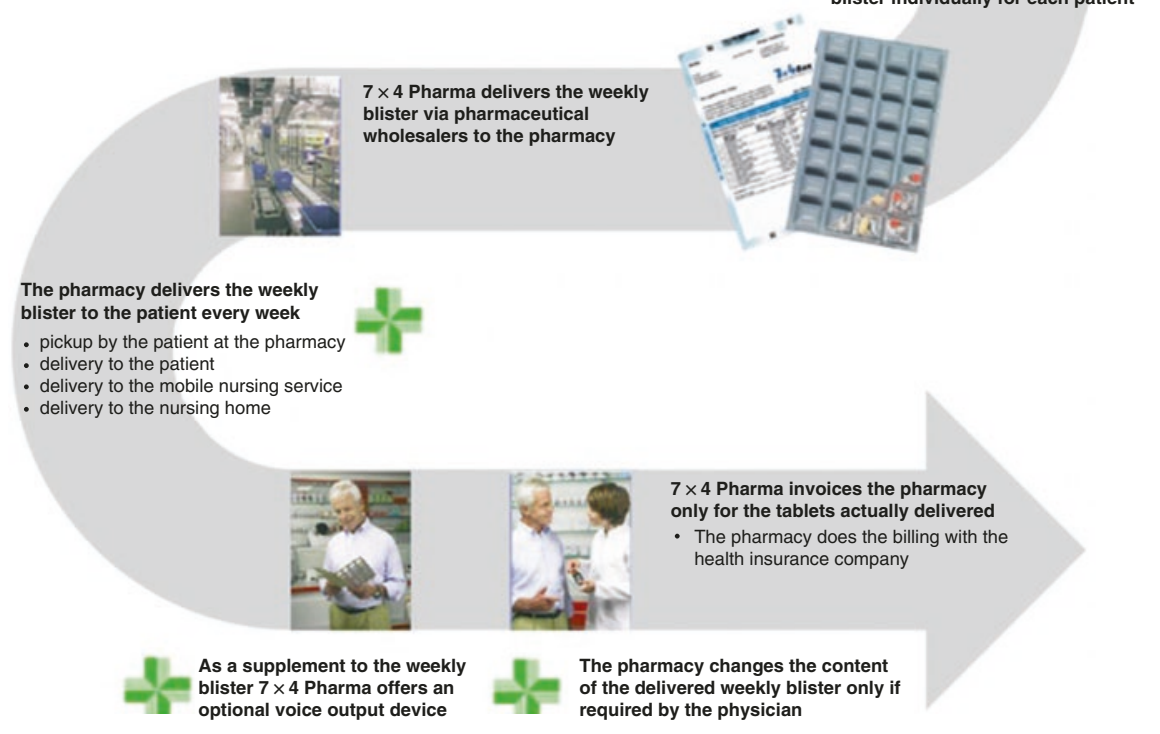

Fig. 10.1 ADD process flow (Kohl 2010, p. 11)

Yet none of these had been formally introduced or regulated in Germany in 2005, and none of these are in place to this day.

The creation and exchange of these documents implies an adjustment of existing practices and involves - apart from the ADD operator - patients, physicians, pharmacies, pharmaceutical wholesalers, caretakers or nursing homes and health insurances as illustrated in Fig. 10.1.

- Physicians use the $7 \times 4$ Pharma software to issue prescriptions based on the medication list.

- Patients take all their prescriptions to one pharmacy.

- The pharmacy registers and checks the prescriptions for critical interactions, dosage and double prescriptions, e.g. pain killers prescribes independently by different specialists. The pharmacy passes the consolidated prescriptions to the ADD operator. 
- A pharmaceutical wholesaler delivers the blisters to the pharmacy.

- The pharmacy is invoiced by $7 \times 4$ Pharma based on the number of tablets delivered.

- The pharmacy charges the insurance providers.

\subsubsection{Debates About ADD in Germany}

Between 2004 and 2007 a number of studies - commissioned by Kohl Medical AG, $7 \times 4$ Pharma's parent company - have been published, which examined different facets of ADD and provided the rationale for industrial ADD at a national level (Glaeske 2007; Lauterbach et al. 2004a, b, 2006, 2007 ).

In 2006, Wille and Wolf (2006) published a study - commissioned by the association of research active pharmaceutical companies (VfA) - on the costs and benefits of secondary blisters, which contradicted the studies by Glaeske, Lauterbach et al. and concluded that ADD is neither cost efficient nor effective.

Meanwhile, in 2009, the $7 \times 4$ Pharma facility went live (Hollstein 2009). Subsequently pilot studies - based on industrial ADD as well as regional blistering - have been conducted in collaboration with health insurance providers in order to assess the effects of ADD in life settings.

At the beginning of 2011, the results of two pilot studies have been published. One was based on industrial ADD (Leker and Kehrel 2011), the other was based on blisters produced by pharmacies (Neubauer 2011; Neubauer and Wick 2011) in cooperation with health insurance providers. The studies provide evidence that ADD contributed to improvements of both medication safety and compliance. Moreover they postulated cost saving of up to $31 €$ per patient per week (Neubauer and Wick 2011).

In spring 2011, the Federation of German Associations of Pharmacists (ABDA) and the National Association of Statutory Health Insurance Physicians (KBV) published a proposal for improved medication supply in Germany, which addressed the same issues of compliance of polypharmacy patients and medication supply (ABDA and KBV 2011b). While the proposal can be seen as complementary to ADD, it refrains from even mentioning the issue of drug administration.

In August 2011, the association of statutory physicians and the association of pharmacies for the state of Brandenburg (Landesapotheker- und Landesärztekammer Brandenburg 2011) issued a position paper, which assessed and rejected ADD. The association of patient individual blister companies (BPAV 2011) issued a critical and angry rebuttal. The association of pharmacies supplying nursing homes (BVKA Schumbach 2013a) has also articulated critique against ABDA's blockade of ADD.

In November $20117 \times 4$ Pharma's production of blisters was discontinued. It had become obvious by then that the regulator was not inclined to fill the gap left in the 2005 law due to the coordinated resistance of ABDA and KBV (Schumbach 2013b). Hypothetically speaking, had the regulator provided reasonable rules for eligibility for patient-specific blisters and for reimbursement of the blister production and the requisite medication review, it could have triggered the development and extension of the information infrastructure and thereby making blistering a viable model. The fact that the 
ABDA and KBV concept paper (ABDA and KBV 2011b) has been published in 2011 and that $7 \times 4$ Pharma was sold during the same year may be more than a coincidence.

In mid 2013, the second industrial provider, AvidiaMed (2013), closed its ADD operation. A pilot study based on the ABDA-KBV proposal (Arzneimittelinitiative Sachsen-Thüringen 2014), initially scheduled to start at the end of 2013, has been delayed by a year (Ziegler 2013).

\subsubsection{Status in 2016: Slow Diffusion and Persistent Opposition}

About 7,5 Mio patients in Germany take five or more medication regularly (Hillienhof 2015). While the two national ADD initiatives have been terminated, local and regional blister initiatives have continued and are gradually extending their operations. In 2011 about $25 \%$ of home care facilities use and pay external blister providers (Rauers 2011). The economic logic for blistering is a combination of quality assurance and outsourcing of preparing the medication for patients: the external production of blisters can usually be done at a lower cost than the preparation of pill boxes in the care homes.

The diffusion of blistering among home care patients is much lower. It is not established as a practice and is rarely recommended by doctors or pharmacists. The daily practices of taking medication is not in scope of a broader debate. Eligibility and reimbursement have not been clarified by the regulator and when pharmacies provide blistering as a free service for their patients, they risk being sued for price dumping (Wessinger 2014).

To this day, there is a strong and outspoken opposition in Germany against blistering by the associations of doctors (KBV), pharmacists (ABDA) and the research active pharmaceutical manufacturers (VfA) industry, and (therefore) not actively pursued by the regulator.

Despite clarifying the legal status of patient specific blisters and the required license for the production in 2005, no subsequent clarification of eligibility, division of responsibilities and reimbursement have been provided by the regulator, which leaves providing blisters for care homes as one of the few economically viable options.

Core ehealth information infrastructure components, notably electronic prescription and electronic patient medication plan, upon which blistering could be more easily extended, have not yet been introduced.

There is neither a public discourse nor research about the benefit and risks of dose administration aids for elderly polypharmacy patients. The official statements against blistering are categorical and do not even leave space for a nuanced reflection of design options.

All this has led to the widespread perception that the issue is "dead" and does not require any further consideration. Notably, even the word "blistering" is largely avoided in the public discourse, except for the dedicated blister community, which seems like a marginalized minority. There are no significant research programs or projects on how to support elderly people in managing their medication. The 
discussion what should be covered by medication management is still ongoing (Dartsch 2013).

\subsection{Analysis}

The field of medication management with the goal to improve medication safety and compliance addresses a complex ensemble of diverse practices, health care governance and regulation as well as technology (codes, standards and artefacts, such as electronic patient health cards). The case underscores that infrastructure evolution is happening over extended periods of time, at a large scale and deeply embedded in practices (Reimers et al. 2012). It highlights not only the role of the installed base, but also the need for aligning the scope of initiatives (from local or regional to national) and the "availability" or state of the installed base at the appropriate level as a prerequisite for infrastructure innovation.

\subsubsection{Deficiencies in Installed Base}

As an attempted infrastructure innovation, the $7 \times 4$ Pharma initiative has been aimed at scaling - from a local or regional level to a national level - and extending existing practices of blistering, building and initiating an evolution of technical components (information infrastructure) and regulatory adjustments. It can be seen as a bold move to create facts that might have engendered a momentum of transformation.

However, it became obvious that neither the necessary supporting practices, such as the compilation, review and sharing of prescriptions and patient medication plan, nor the underlying information infrastructure (electronic prescriptions and digital mediation plans, electronic communication between physicians and pharmacies and software supported review of medication plans), nor the supporting regulation (rules for eligibility and reimbursement) had emerged at a national level.

There is still no mechanism in place to share medication records among health care professionals on a routine basis. Even though each health care professional is in principal obliged to control for critical interactions, there is no clear division of labour between pharmacists and doctors regarding the monitoring of medication effects over time. Both professions regularly rely on the vigilance of patients and their helpers. New routines, roles and linkages between doctors, patients, pharmacists, the blister operator and the health insurance provider were developed during the pilot project, but did not spread beyond the pilot and did not persist once the pilot was terminated. In other words, the installed base of local and regional practices and initiatives, locally deployed information systems and existing regulation of blistering, were not suitable for or not aligned with the goals of building a national infrastructure.

Obviously, $7 \times 4$ Pharma had been aware of the situation and has made major efforts throughout the pilot project to initiate a rudimentary information infrastructure development themselves. They provided software for medication review, the exchange 
of prescriptions and medication plans to physicians and pharmacists, and suggested ways of collaborating with the clearly articulate goal to improve the quality and efficiency of patient care. The design of the pilot study and the research based on the pilot (Leker and Kehrel 2011) were in line with the principles of benefits assessment as articulated by the G-BA ${ }^{4}$ and the regulation about pilot projects in health care $(\S \S$ 63-65 SGB V). Still the lack of both, regulatory adjustments and standards has inhibited the proliferation of these practices that have been developed during the pilot.

One might interpret it as a bootstrapping approach, which - however - assumed that it would be sufficient to jumpstart the development dynamics, which would then convince the decision making bodies, the Federal Joint Committee (G-BA) and regulating authorities, to take over.

\subsubsection{An "Installed Base of Opposition"}

$7 \times 4$ Pharma encountered what we would describe as an installed base of opposition. This opposition is multi-faceted and driven by different rationales. We have identified four key concerns:

1. $7 \times 4$ Pharma and its parent company, Kohl Medical AG,${ }^{5}$ have been perceived as a competitor constituting a new entrant into the health care market (Bellartz 2006).

2. The proposal of a mandatory medication list, i.e. the assortment of 400 medicines for blistering, has drawn critique from the doctors association (KBV).

3. The association of research active pharmaceutical manufacturers (VFA) funded research to proof the ineffectiveness of ADD and has been quite outspoken in its critique.

4. Innovations of the IT infrastructure, such as electronic prescriptions and electronic medication plans, and a wider dynamics of innovation have been critically reviewed by KBV.

The $7 \times 4$ Pharma design proposal caused predictable concerns or outright resistance across a large set of actors in the health care system:

1. The existing blister community (pharmacies and blister centres) inevitably perceived $7 \times 4$ Pharma as competitor and the ADD pilots as potentially disruptive innovation, even though they shared an interest in regulatory amendments in favour of blistering.

As blistering is particularly relevant for pharmacies who deliver to care homes and nursing homes, home care providers and polypharmacy patients, many pharmacies

\footnotetext{
${ }^{4}$ For more information about the mandate of the G-BA: http://www.english.g-ba.de/legalmandate/ procedures/methods/evidence/

${ }^{5}$ Kohl Medical AG also owns kohlpharma, the largest European importer for medication.
} 
see themselves as not really affected by the issue. ABDA as a pharmacy association appears to have decided to speak for the latter group rather than for the former. Even though the $7 \times 4$ Pharma proposal goes to great pains to emphasize and indeed strengthen the role of the pharmacists (Kohl 2010), there still may be a concern about potential disintermediation, i.e. direct delivery of blister packs to the patients. Opponents of blistering aimed to undermine the credibility of $7 \times 4$ Pharma's ADD initiative, which provided a prominent and relatively easy target given the specific design proposals, in particular the positive list, and the position of Kohl Medical AG. Speculative concerns, such as the risk of a monopoly of $7 \times 4$ Pharma, or even conspiracy theories about the intended vertical control of the medication market by Kohl were two examples of the employed tactics (Bellartz 2006). By aiming at ADD, they indirectly also undermined the credibility of the regional blister centres. The opposition appears to follow distinct tactics of focussing on controversial design issues while not engaging in any dialogue about possible design improvements, and creating their own initiative, which could be regarded as a red herring, while avoiding the issue of blistering, and causing or accepting delays. The official statements about blistering by physician and pharmacist associations (Landesapotheker- und Landesärztekammer Brandenburg 2011) have been criticized as one sided, bloating risks and obstructing blistering, without recognizing the facts of widely established practices of blistering and using dose administration aids in Germany and - more widespread - internationally (BPAV 2011; Schumbach 2013a). We have not found evidence of a willingness of ABDA and KBV to recognize the need for dose administration aids and to engage in a dialogue about improvements of the design of ADD or blistering in general in order to better address patients' needs or to suggest or conduct further research to clarify the contested issues. The benefits of patient specific blisters, if properly administered, have been shown by several studies (Leker and Kehrel 2011; G. Neubauer and Wick 2011), yet these results seem to be "inconvenient truths", which are refused and opposed.

2. Many doctors and their association $(\mathrm{KBV})$ are against, what has been referred to as the positive list, a mandatory list of medication that can be provided by $7 \times 4$ Pharma,

Since 2006 insurance companies can and do negotiate discounts with pharmaceutical manufacturers (Bundesministerium für Gesundheit 2006). This could pose a potential conflict with the mandatory list of medication suggested by $7 \times 4$ Pharma.

3. The association of research active pharmaceutical manufacturers (VfA), which commissioned an academic study aiming directly at $7 \times 4$ Pharma's initiative, had strong reasons for their opposition. If ADD would be introduced in Germany as suggested by $7 \times 4$ Pharma, they would have a lot to lose: (a) control over which medication is dispensed to the participating polypharmacy patients, (b) according to the pilot results, less medication would be discarded because of the 
provision in weekly blister packs instead of larger retail packages, (c) medication in blisters can be provided at a lower price (Pradel 2015), (d) eventually the ADD operators may be able to procure medication in large packages for the use in blister automats - like in Finland - rather than the current retail packages. The widely cited study (Wille and Wolf 2006), whose content was reiterated by VfA itself (Verband Forschender Arzneimittelhersteller e.V. (VFA) 2009) proved to be very effective in discrediting the efficiency and effectiveness of patient specific blisters based on conceptually derived claims, yet without providing primary empirical evidence. In that way the study would not qualify as evidence according to the standards of the Federal Joint Committee (G-BA).

4. There is widespread reservation or even open resistance against electronic prescription among doctors (Franke 2010; Institut für Demoskopie Allensbach 2010). While the implementation of the medication plan is welcomed in principle, specific concerns still remain (Hillienhof 2015) and the responsibilities regarding compiling and reviewing a comprehensive medication plan are not clear yet (ABDA - Bundesvereinigung Deutscher Apothekerverbände 2015).

We suspect that the concern, the discussion about patient specific blisters might open a pandora's box of subsequent, uncontrollable changes in the health care system, is a key reason for the opposition. In a description of his research on his web site, Neubauer states that based on the insights of the ADD pilot projects, he will be exploring possible improvements of the health care system at large. ${ }^{6}$

Based on the prevalent opposition, the regulator decided not to take any action in favour of blistering (Schumbach 2013b): implementation issues of the 2005 regulation such as eligibility for blistering, reimbursement of costs, roles and responsibilities for aggregating and checking medication plans, let alone the underlying IT infrastructure for e-Prescription and electronic medication plans were left open.

\subsection{Discussion}

In this section we will be looking at different lenses and interpretations of the notion of installed base as well as the German health care system's propensity to innovation. The case provides different insights on the emergence of infrastructures and the related installed base.

First, it illustrates the various, interconnected facets of the installed base: constellations of practices, specifically of an integrated medication management, health care regulation and governance, and technology: "there is a historicity stemming from the manner sediments of earlier solutions, entrenched routines, prevailing perceptions and social institutions constitute and solidify existing practices." (Aanestad et al. 2005, p.5, see also Aanestad and Jensen 2011, p.162). The introduction of ADD would imply a transformation and extension of practices of medication

\footnotetext{
${ }^{6}$ See: project description "Patient individual secondary pharmaceutical blister packs in care homes" on http://ifg-muenchen.com/arzneimittel-und-medizinprodukte/
} 
management (consolidation of prescriptions, creating and reviewing the medication plan) and related information sharing practice (between specialist doctors and the GP, GP and pharmacy, pharmacy and ADD operator), practices of distributing medication and practices of invoicing and reimbursing medication. This transformation will create uncertainties as to who - physician or pharmacist - will be in charge, what will be the basis of reimbursement (if any) and how will the coordination between physician or pharmacist be organized. Moreover, the proposals for ADD relate to entrenched opposition of doctors and pharmacists. Doctors fear to lose control over their choice of medication, something which is already happening to some degree as a result of health insurance policies. Pharmacists fear to lose revenue as a result of new business models (Online pharmacies) or new entrants (ADD operators), who might try to bypass community pharmacies.

This illustrates, second, the possibly inhibiting role of an installed base of practices, which are not open for discourse, experimentation and innovation, instead seem to focus more on caring for their own economic interests, retaining control and perpetuating the status quo. In particular the national doctors' and pharmacists' associations (KBV and ABDA) appear to be entrenched in politics and lobbying for the majority of their members. The blatant unwillingness even to engage in a dialogue about blistering is striking.

Third, it shows the difficulties of scaling a medication infrastructure before the relevant installed base has been scaled as well or is at least ready for scaling. This includes a momentum of technical innovations and related norms and practices. In this way, the installed base does not only highlight the temporal dynamics of infrastructure development and evolution, but the installed base also becomes a platform and indeed background upon which novel or specialized infrastructures can be built or scaled.

Turned around, this might suggest an expectation that the successful scaling of an infrastructure, specifically ADD, might spur and accelerate the adjustment and adaptation of the underlying installed base and cause a political momentum and reorientation. $7 \times 4$ Pharma's goal was to convince the regulator to take action and provide the necessary steps by delivering a proof of concept (pilot installation) with participation of patients, doctors, pharmacists, insurance companies and academics. Insurance companies aided by academics acknowledged the effectiveness of the solution and were meant to provide the necessary credibility.

\section{Conclusion}

We have interpreted the ADD initiatives in Germany as attempts to scale scattered local and regional practices of blistering and establish a national infrastructure. The analysis of the failure of these initiatives revealed a lack of an appropriate or even appropriately flexible installed base in terms of established practices of physicians and pharmacists as well as cooperation between them, enabled by regulation and technology, specifically a patient information infrastructure encompassing electronic prescription and patient medication plans.

While both national-level initiatives can also be seen as bootstrapping attempts to foster the development of the bespoke installed base, they encoun- 
tered categorical opposition and resistance. While in particular in the case of the association of the pharma manufacturers (VfA), the opposition can be explained by obvious economic interests, the resistance of physician and pharmacy associations is less obvious. Both also represent members who are not only in favour of, but are actually producing and distributing blisters to their patients.

The tactics of opposition seem to suggest a profoundly negative attitude, which is not even open to discourse and reasoning. It is astounding that the international examples of practice, critical discourse and research about dose administration aids as integrated part of medication management dose are not actively considered.

A justification for the resistance to infrastructure innovation might reflect prior experience of government initiated large scale health care infrastructure projects, such as the electronic patient health card. Especially the health card appears as a typical example of a megaproject (Flyvbjerg et al. 2003), which encountered huge resistance, delays, cost overruns and in the end achieved much less then has been promised at the start. Given this experience, an attitude of hesitation becomes understandable.

The governance structure of the German health care system is based on cooperatist consensus building and decision making prior to regulation. The Federal Joint Committee (G-BA) is the decision-making body of the joint governance of physicians, dentists, hospitals and health insurance providers in Germany (www. english.g-ba.de). The G-BA has an innovation fund, which will be available as of 2016 in order to facilitate and study new forms of medical care. Pilot projects for medication safety for multimorbid patients are among the suggested initiatives. This initiative might be read as an admission that innovative forms of care require more attention in Germany.

\subsection{Appendix: List of Acronyms}

\begin{tabular}{l|l}
\hline ABDA & Federation of German Associations of Pharmacists \\
\hline ADD & $\begin{array}{l}\text { Automatic dose (or drug) dispensing (ADD), the industrial production of } \\
\text { patient-specific dose administration aids, e.g. blister packs, typically for solid } \\
\text { oral medicines for a defined period, e.g. 7 days. }\end{array}$ \\
\hline AkdÄ & Drug Commission of the German Medical Association \\
\hline Blistering & $\begin{array}{l}\text { The provision of patient specific dose administration aids in form of blister } \\
\text { packs. }\end{array}$ \\
\hline BPAV & $\begin{array}{l}\text { Bundesverband Patientenindividueller Arzneimittelverblisterer e.V. (national } \\
\text { association of producers of patient specific blister packs). }\end{array}$ \\
\hline BVKA & National Association of Pharmacies supplying care homes or nursing homes. \\
\hline GB-A & $\begin{array}{l}\text { The Federal Joint Committee (G-BA) is the highest decision-making body of the } \\
\text { joint self-government of physicians, dentists, hospitals and health insurance } \\
\text { funds in Germany. [http://www.english.g-ba.de/] }\end{array}$ \\
\hline KBV & National Association of Statutory Health Insurance Physicians \\
\hline VfA & Association of Research Active Pharmaceutical Manufacturers \\
\hline
\end{tabular}




\section{References}

Aanestad M, Jensen T B (2011). Building nation-wide information infrastructures in healthcare through modular implementation strategies. The Journal of Strategic Information Systems, 20(2), 161-176.

Aanestad M, Monteiro E, Kimaro H, Macombe E, Macueve G, Mukama F, Muquingue H, Nhampossa J, Lungo J. Strategies for development and integration of health information systems: coping with historicity and heterogeneity (No. 5/2005). Oslo. 2005. Retrieved 06 Jan 2017 from http://folk.uio.no/systarb/wp/052005.pdf.

ABDA - Bundesvereinigung Deutscher Apothekerverbände. Kiefer: Medikationsplan im E-Health-Gesetzentwurf ist Etikettenschwindel. ABDA Pressemitteilungen. 2015. Retrieved 14 Sept 2015, from http://www.abda.de/pressemitteilung/artikel/kiefer-medikationsplan-im-ehealth-gesetzentwurf-ist-etikettenschwindel/.

ABDA, KBV. Zukunftskonzept Arzneimittelversorgung. 2011a. Retrieved 31 May 2016, from http://www.abda.de/fileadmin/assets/Pressetermine/2011/ABDA_KBV/Zukunftskonzept_ 07_10_2011_KBV_ABDA_Homepage.pdf.

ABDA, KBV. Zukunftskonzept Arzneimittelversorgung - Gemeinsames Eckpunktepapier. Berlin. 2011b. Retrieved 31 May 2016, from http://www.kbv.de/html/2947.php.

AkDÄ. Aktionsplan Arzneimitteltherapiesicherheit (AMTS). 2007. Retrieved 31 May 2016, from www.akdae.de/AMTS/Aktionsplan/.

Arzneimittelinitiative Sachsen-Thüringen. ARMIN - Die Arzneimittelinitiative SachsenThüringen. 2014. Retrieved 21 Mar 2015, from http://www.arzneimittelinitiative.de/ grundlagen/.

Ärztliches Zentrum für Qualität in der Medizin (ÄZQ). Sichere Arzneimitteltherapie. 2011; doi:10.6101/AZQ/000002.

AvidiaMed. Pressemeldung: Körber fokussiert Kernaktivitäten der Sparte PharmaVerpackungssysteme. 2013. Retrieved 06 Jan 2017, from http://www.koerber.de/cn/medien/ aktuelle-meldungen/meldung-liste/article/koerber-fokussiert-kernaktivitaeten-der-sparte-pharma-verpackungssysteme.html.

Bell JS, Johnell K, Wimmer BC, Wiese MD. Multidose drug dispensing and optimising drug use in older people. Age Ageing. 2013;42(2013):556-8.

Bellartz T. Apothekenmarkt - Die Expansion des Edwin Kohl. Pharmazeutische Zeitung online. 2006. Retrieved 06 Jan 2017, from www.pharmazeutische-zeitung.de/index.php?id=849.

Bierwirth R, Paust R. Compliance und empowerment in der Diabetologie. Bremen: UNI-MED; 2004

Borchers D. Elektronische Gesundheitskarte: Feldtest muss verschoben werden. Heise online. 2015. Retrieved 31 May 2016, from http://www.heise.de/newsticker/meldung/ElektronischeGesundheitskarte-Feldtest-muss-verschoben-werden-2763723.html.

BPAV. Entgegnung des BPAV auf das gemeinsame Positionspapier der Landesapotheker- und Landesärztekammer Brandenburg vom August 2011. 2011. Retrieved from http://www.blisterverband.de/.

Braun B, Marstedt G. Non-compliance bei der Arzneimitteltherapie: Umfang, Hintergründe, Veränderungswege. In: Böcken J, Braun B, Reipschläger U, editors. Gesundheitsmonitor 2011. Gütersloh: Bertelsmann Stiftung; 2011. p. 56-76.

Bundesärztekammer. Beschlussprotokoll des 111. Deutschen Ärztetages vom 20. bis 23. Mai 2008 in Ulm. Berlin. 2008. Retrieved 31 May 2016, from http://www.bundesaerztekammer.de/aerztetag/beschlussprotokolle-ab-1996/111-daet-2008/.

Bundesärztekammer. Beschlussprotokoll des 118. Deutschen Ärztetages in Frankfurt am Main vom 12.05. bis 15.05.2015. Berlin. 2015. Retrieved 31 May 2016, from https://www.padeutschland.de/files/beschlussprotokoll2015.pdf.

Bundesministerium für Gesundheit. Gesetz zur Verbesserung der Wirtschaftlichkeit in der Arzneimittelversorgung (AVWG) tritt zum 1. Mai 2006 in Kraft. Pressemitteilung. 2006. Retrieved 20 Sept 2015, from http://www.bmg.bund.de/presse/pressemitteilungen/2006-02/ arzneimittelversorgungs-wirtschaftlichkeitsgesetz-tritt-in-kraft.html. 
Bundesregierung der Bundesrepublik Deutschland. Entwurf eines Gesetzes für sichere digitale Kommunikation und Anwendungen im Gesundheitswesen. Berlin, Germany. 2015. Retrieved 06 Jan 2017, from http://www.bmg.bund.de/fileadmin/dateien/Downloads/E/eHealth/150527_ Gesetzentwurf_E-Health.pdf.

Cheung K-C, van den Bemt PMLA, Bouvy ML, Wensing M, De Smet PAGM. Medication incidents related to automated dose dispensing in community pharmacies and hospitals - a reporting system study. PLoS ONE. 2014;9(7):e101686.

Corlett AJ. Caring for older people: aids to compliance with medication. BMJ. 1996;313(7062):926-9.

Dartsch D. Serie AMTS: Medikationsmanagement hier und anderswo. Pharmazeutische Zeitung Online. 2013. Retrieved 31 May 2016, from http://www.pharmazeutische-zeitung.de/index. php?id=50085.

Drews P, Schirmer I. The failed implementation of the electronic prescription in Germany - a case study. In Proceedings of the 23rd European Conference on Information Systems. Münster. 2015. p. $1-15$.

Düsing R. Medikamentöse Therapie mit verblisterten Arzneimitteln: Möglichkeiten und Chancen. Bonn. 2006. Retrieved 31 May 2016, from http://www.kohlpharma.de/_data/mediapool/download_daten_assist/1171892367_070125_Duesing-Studie.pdf.

Elmer A. Großprojekt Elektronische Gesundheitskarte. IM+io, (03), 20-26. 2014.

Flyvbjerg B, Bruzelius N, Rothengatter W. Megaprojects and risk - an anatomy of ambition. Cambridge: Cambridge University Press; 2003.

Franke N. Elektronische Gesundheitskarte: Ärzte lehnen E-Rezept ab. Pharmazeutische Zeitung Online 35. 2010. Retrieved 31 May 2016, from http://www.pharmazeutische-zeitung.de/index. php?id=35100.

GKV Spitzenverband. Das Wichtigste über die elektronische Gesundheitskarte. 2015. Retrieved from https://www.gkv-spitzenverband.de/media/dokumente/presse/publikationen/Flyer_eGK_2015.pdf.

Glaeske G. Analyse der Verordnungen in einer GKV-Population im Hinblick auf die Eignung für eine individuelle Verblisterung. 2007. Retrieved 31 May 2016, from www.7x4pharma.de/_ shared/p_file_download.php?locale=de\&files_id $=2803$.

Haefeli WE, Hoppe-Tichy T, Seidling H. Abschlussbericht - best practice strategien in Europa als Grundlage fürdieOptimierung vonArzneimittelverordnung, anwendung und das Therapiemonitoring in Deutschland. Heidelberg: Universitätsklinikum Heidelberg; 2012. Retrieved 4 January 2017 from https://www.bundesgesundheitsministerium.de/fileadmin/Dateien/Publikationen/Gesundheit/ Bericht/Abschlussbericht_BestPractice_AMTS_20160226_deutsche_Abb.pdf

Hillienhof A. KBV fordert Änderungen am geplanten Medikationsplan. Berlin: Deutsches Ärzteblatt; 2015.Retrieved 06 Jan 2017, from http://www.aerzteblatt.de/nachrichten/63578/ KBV-fordert-Aenderungen-am-geplanten-Medikationsplan.

Hollstein P. Kohl gibt Startschuss für 7×4-box. APOTHEKE ADHOC. 2009. Retrieved 06 Jan 2017, from http://www.apotheke-adhoc.de/nachrichten/nachricht-detail/kohl-gibt-startschussfuer-7x4-box $/$ ? $=0 \% 3 \mathrm{Ft} \% 3 \mathrm{Ft} \% 3 \mathrm{Ft} \% 3 \mathrm{Ft} \% 3 \mathrm{Ft} \% 3 \mathrm{Ft} \% 3 \mathrm{D} 1 ? \mathrm{t}=1$.

Institut für Demoskopie Allensbach. Der Einsatz von Telematik und Telemedizin im Gesundheitswesen: Ergebnisse einer Repräsentativbefragung. eHealth-Report: Institut für Demoskopie Allensbach. Allensbach. 2010. Retrieved 06 Jan 2017, from http://www.bundesaerztekammer.de/fileadmin/user_upload/downloads/pdf-Ordner/Telemedizin_Telematik/ Telemedizin/eHealth_Bericht_kurz_final_1_.pdf.

Kohl E. Patient compliance and treatment success individualised blister packs using the $7 \times 4$ box as an example. 2010. Retrieved 06 Jan 2017, from http://www.costeff.eu/_shared/p_file_download.php?files_id=70.

Landesapotheker- und Landesärztekammer Brandenburg. Positionspapier: Qualitätsgesicherte Arzneimitteltherapie und Arzneimittelversorgung von Patienten, die in unterstützenden Wohnformen (Heimen) betreut werden. 2011. Retrieved from http://www.laekb.de/50ueberUn s/20Beitraege/90Archiv/70Archiv2011/110509_Positionspapier110818.pdf.

Lauterbach KW, Gerber A, Lüngen M. Internationale Erfahrungen mit der Verblisterung von Arzneimitteln. Köln. 2004a. Retrieved 06 Jan 2017, from https://www.7x4-pharma.com/_ shared/p_file_download.php?files_id=2798. 
Lauterbach KW, Gerber A, Stollenwerk B, Lüngen M. Verblisterung von Arzneimitteln für Bewohner von Alten-und Pflegeheimen und in der häuslichen Pflege: Beschreibung und Bewertung eines Pilotprojekts (September 2004 bis Dezember 2005) Verblisterung von Arzneimitteln. Köln. 2006. Retrieved 06 Jan 2017, from www.7x4pharma.de/_shared/p_file_ download.php?files_id=2801\&locale=de.

Lauterbach KW, Lüngen M, Gerber A. Nutzung der Verblisterung von Arzneimitteln im Rahmen von Disease-Management-Programmen. Köln. 2004b. Retrieved 06 Jan 2017, from https:// www.7x4-pharma.com/_shared/p_file_download.php?files_id=2797.

Lauterbach KW, Lüngen M, Gerber A, Kohaupt I, Büscher G. Quantifizierung der Fehlwurfrate beim Stellen fester oraler Darreichungsformen in drei Pflegeheimen. Köln. 2007. Retrieved 06 Jan 2017, from https://www.7x4-pharma.com/_shared/p_file_download.php?files_id=2799.

Leker J, Kehrel U. Abschlussbericht der Studie zur patientenindividuellen Arzneimittelverblisterung in Berliner Pflegeeinrichtungen Struktur des Berliner Pilotprojektes (Präsentation). 2011. Retrieved 06 Jan 2017, from http://www.wmscdn.de/uploads/9758/9758.pdf.

Lochner S, Buitkamp M, Kirch W. Polypharmazie - wie beurteilen Patienten die Medikamentenverschreibung der Ärzte? In: Böcken J, Braun B, Reipschläger U, editors. Gesundheitsmonitor 2011. Gütersloh: Bertelsmann Stiftung ; 2011. p. 77-92.Retrieved 06 Jan 2017, from http://gesundheitsmonitor.de/studien/detail/?tx_itaoarticles_pi1[article]=169\&tx_ itaoarticles_pi1[action]=show\&tx_itaoarticles_pi1 [controller]=Article\&cHash=9064ed16fc5 925 bcca27a905a5c86f73.

Neubauer G. Patientenindividuelle Arzneimittel-Verblisterung für Bewohner in Pflegeheimen Bericht zum Modellprojekt der AOK Bayern. Berlin. 2011. Retrieved 06 Jan 2017, from www. bvka.de/Veranstaltungen/Neubauer\%20BVKA\%20Berlin\%2024-10-11.pdf.

Neubauer G, Wick A. Patientenindividuelle für Bewohner von Pflegeheimen (PIVP) Zusammenfassung der wichtigsten Ergebnisse des Modellprojekts der AOK Bayern. 2011. Retrieved 06 Jan 2017, from http://www.wmscdn.de/uploads/9756/9756.pdf.

Neumann P.. Rösler stoppt die elektronische Gesundheitskarte. Die Welt. 2009, November. Retrieved 06 Jan 2017, from https://www.welt.de/politik/deutschland/article5267140/Roeslerstoppt-die-elektronische-Gesundheitskarte.html.

Patienten-individuelle Verblisterung in Deutschland - eine Bestandsaufnahme. Der BlisterBlog Patientenindividuelle Arzneimittelverblisterung. 2010. Retrieved from http://verblistern.info/ blog/.

Pradel J. BGH glaubt nicht an Stiickel-Boni. Apotheke Adhoc. 2015, August 11. Retrieved 06 Jan 2017, from http://www.apotheke-adhoc.de/nachrichten/apothekenpraxis/nachricht-detailapothekenpraxis/verblisterung-bundesgerichtshof-bgh-erlaubt-rabatte-fuer-rx-teilmengen/.

Rauers J. Pflegeheime setzen Apotheken unter Druck. Apotheke adhoc. 2011. Retrieved 06 Jan 2017, from http://www.apotheke-adhoc.de/nachrichten/nachricht-detail/pflegeheime-setzenapotheken-unter-druck/?t=1.

Reimers K, Johnston RB, Klein S. Evolution of inter-organizational information systems on long timescales: a practice theory approach. In: Vaidya K, editor. Inter-organizational information systems and business management: theories for researchers. Hershey: IGI Global; 2012.

Royal Pharmaceutical Society. Improving patient outcomes The better use of multi - compartment compliance aids. 2013. Retrieved 06 Jan 2017, from http://www.rpharms.com/support-pdfs/ rps-mca-july-2013.pdf.

Schersch S. E-Health-Gesetz: Apotheker in der Nebenrolle. Pharmazeutische Zeitung Online. 2015. Retrieved 06 Jan 2017, from http://www.pharmazeutische-zeitung.de/index. php?id=58157.

Schumbach K.. Blisterapotheken: ABDA mauert. Apotheke adhoc. 2013a. Retrieved 21 Aug 2013, from http://www.apotheke-adhoc.de/nachrichten/nachricht-detail/bvka-tagung-steinwegverblistern-muss-honoriert-werden/.

Schumbach K. Kein Honorar für Verblisterung. Apotheke adhoc. 2013b. Retrieved 30 Aug 2013, from http://www.apotheke-adhoc.de/nachrichten/nachricht-detail/verblisterunghennrich-verblistern-ist-kein-thema/?tx_ttnews\%5BsViewPointer\%5D=1\&cHash=0315a0f1b $5 a 6 f 6 b 6 e 67 f c a d 1417 b 375 c$.

Stafford N. Germany is set to introduce e-health cards by 2018. BMJ. 2015;h2991. 
Tuffs A. Germany plans to introduce electronic health card. BMJ. 2004;329:131.

Verband Forschender Arzneimittelhersteller e.V. (VFA). Industrielle Neuverblisterung von Arzneimitteln. Berlin. 2009. Retrieved 06 Jan 2017, from www.vfa.de/download/posneuverblisterung.pdf.

VFA. Die elektronische Gesundheitskarte: Was sie kann und was sie noch können soll. 2014. Retrieved 06 Jan 2017, from http://www.vfa-patientenportal.de/patienten-und-versorgung/ was-sie-kann-und-was-sie-noch-koennen-soll.html.

Wessinger B. Apotheker begrüßen Blister-Dumpingverbot. Apotheker Zeitung. 2014. Retrieved 06 Jan 2017, from https://www.deutsche-apotheker-zeitung.de/daz-az/2014/az-46-2014/ apotheker-begruessen-blister-dumpingverbot.

Wille E, Wolf M. Neuverblisterung von Arzneimitteln. Gutachten im Auftrag des Verbandes Forschender Arzneimittelhersteller e.V. (VFA) Endbericht. 2006. Retrieved 06 Jan 2017, from http://www.vfa.de/pm20060627.

World Alliance for Patient Safety. Summary of the evidence on patient safety: implications for research. edited by Ashish Jha. Geneva. 2008. Retrieved 06 Jan 2017, from http://www.who.int/ patientsafety/information_centre/20080523_Summary_of_the_evidence_on_patient_safety.pdf.

Ziegler J. Politik: Mit neuem Namen: ABDA/KBV-Modell startet im Januar: DAZ.online. DAZ. online. 2013. Retrieved 06 Jan 2017, from http://www.deutsche-apotheker-zeitung.de/politik/ news/2013/10/11/abdakbv-modell-startet-im-januar/11211.html.

Open Access This chapter is distributed under the terms of the Creative Commons AttributionNonCommercial 2.5 International License (http://creativecommons.org/licenses/by-nc/2.5/), which permits any noncommercial use, duplication, adaptation, distribution and reproduction in any medium or format, as long as you give appropriate credit to the original author(s) and the source, provide a link to the Creative Commons license and indicate if changes were made.

The images or other third party material in this chapter are included in the chapter's Creative Commons license, unless indicated otherwise in a credit line to the material. If material is not included in the chapter's Creative Commons license and your intended use is not permitted by statutory regulation or exceeds the permitted use, you will need to obtain permission directly from the copyright holder. 